\title{
The Government as Litigant: Further Tests of the Case Selection Model
}

Theodore Eisenberg, Cornell University, and

Henry Farber, Princeton University

We develop a model of the plaintiff's decision to file a lawsuit that has implications for how differences between the federal government and private litigants translate into differences in trial rates and plaintiff win rates at trial. Our case selection model generates a set of predictions for relative trial rates and plaintiff win rates, depending on the type of case and whether the government is defendant or plaintiff. To test the model, we use data on about 474,000 cases filed in federal district court between 1979 and 1994 in the areas of personal injury and job discrimination, in which the federal government and private parties work under roughly similar legal rules. We find broad support for the predictions of the model.

\section{Introduction}

The process by which potential plaintiffs decide whether to pursue a claim by filing a lawsuit has important implications for case outcomes,

The data used in this article (Federal Court Cases: Integrated Data Base, 19702000 ICPSR Study No. 8429) were originally collected by the Administrative Office of the U.S. Courts and the Federal Judicial Center. The data were made available by the Inter-university Consortium for Political and Social Research. Neither the Center nor the Consortium bears any responsibility for the analyses presented here. We would like to thank for its computer and data support the Cornell Institute for Social and Economic Research. Much of the work on this article was completed while Professor Farber was a John M. Olin Fellow at Cornell Law School. An earlier version of this study was presented at the 1996 annual meeting of the American Law and Economics Association. We thank two anonymous referees for useful comments.

Send correspondence to: Henry Farber, Industrial Relations Section, Firestone Library, Princeton University, Princeton, NJ 08540; Fax: (609) 258-2907; E-mail: farber@princeton.edu. 
including the trial rate and the success rate at trial. In an earlier article (Eisenberg and Farber, 1997) we develop and test a theory of case selection that predicts different trial rates and trial win rates for corporations and individuals based on hypothesized differences in the variance of their litigation costs. In this study we provide a further test of the case selection model by extending our analysis to cases involving the United States as litigant, both as plaintiff and defendant.

Understanding federal government litigation is important in its own right because it comprises a substantial portion of the federal courts' business. Cases in which the United States's presence as a party formed a basis for federal jurisdiction accounted for $29.3 \%$ of the 5,017,603 federal civil nonbankruptcy cases terminated from January 1, 1979, to September 30, 2000 , and for $15.6 \%$ of the 171,217 cases that terminated by judgment after trial. To the extent that the government has distinctive characteristics as a litigant, comparison of its litigation patterns with those of private litigants provides an important empirical test of the case selection model.

In the next section we describe two substantive areas in which the legal standards governing cases with the United States and with private parties are similar: personal injury torts and job discrimination. Cases in these areas will form the basis of our empirical analysis.

In section 3 we develop a model of the plaintiff's decision to file a lawsuit (a case selection model) with implications for trial rates and plaintiff win rates at trial. The model implies that trial rates will be inversely related to defendant costs and to the probability of defendant liability. The model also implies that the probability of a plaintiff win at trial is directly related to plaintiffs' costs and to the probability of defendant liability and inversely related to defendants' costs and the stakes of the case. The model interprets costs broadly to include not only pecuniary costs but also the psychological, emotional, and other difficult-to-quantify factors associated with litigation for private litigants (Eisenberg and Farber, 1997). Government litigants, who need not worry about profitable performance in the same manner as private litigants, and who operate in a different institutional structure, are likely to have costs, broadly defined, that differ from private litigants'.

In sections 4 and 5 we discuss likely differences between the government and private parties as litigants in tort and job discrimination cases. Although the basic legal standards governing tort and job discrimination 
cases between the government and private parties are similar, we note four differences between the characteristics of government and private action: (1) the government has lower costs (including less aversion to litigating a case to trial) than do private parties as defendants in both tort and job discrimination cases; (2) the stakes are lower in both tort and job discrimination cases with the government as defendant, relative to cases with private parties as defendant; (3) the government as plaintiff in job discrimination cases generally brings cases of higher quality (higher probability of liability) than do private plaintiffs; and (4) average litigation costs among private plaintiffs in job discrimination cases are lower than the average government litigation costs in the same role.

The selection model developed in section 3 has clear implications for how these differences will affect case outcomes. We predict that the trial rate will be higher and the plaintiff win rate will be higher in cases in which the government is defendant (relative to cases with private defendants). We also predict that the trial rate will be lower and the plaintiff win rate will be higher in job discrimination cases in which the government is plaintiff (relative to job discrimination cases with private plaintiffs).

In section 6 we describe the data we use for the empirical analysis. These data, on about 474,000 cases filed in federal district court between 1979 and 1994 in the areas of personal injury and job discrimination, are extracted from the Federal Court Integrated Data Base, made available through the Inter-university Consortium for Political and Social Research.

The results of the empirical analysis are contained in section 7 . We find support for all of the predictions save one. The single anomalous result is that the plaintiff win rate in job discrimination cases with the government as defendant is lower than the plaintiff win rate in job discrimination cases with private defendants. The results confirm the need to consider the prefiling selection process in interpreting postfiling patterns of case outcomes.

\section{Areas with Common Legal Standards for Both Government and Private Litigants}

Analyzing the government as litigant requires classes of cases that involve governments and private parties in the same roles. In addition, 
to allow for meaningful comparison, similar legal standards should govern private and government litigants, and any differences in legal standards should have clear implications for the characteristics of cases filed. In general, litigation involving the United States is not typical of the mass of litigation. Cases initiated by the government include a massive number of highly successful, quickly resolved collection actions. ${ }^{1}$ Even noncollection contract litigation involving the government may differ from private litigation. A contract case against the government may not be fundamentally the same as a contract case against a private party. A whole subfield of government contract law exists.

At least two subject areas contain both government and private litigants and share governing legal standards: tort cases and job discrimination cases, and we restrict our analysis to case outcomes in these areas. In the remainder of this section, we outline the legal standards in these areas and note some clear differences between the laws governing private and government litigants. We will rely on these differences to generate most of the testable implications of the selection model for case outcomes.

\subsection{Tort Cases Based on State Law}

Federal court tort cases in which the federal government is the defendant are, under the Federal Tort Claims Act (FTCA), based on state law. The law of the state where the tort occurs governs the action, and the federal government is expressly made liable when a private party would be liable. 28 U.S.C. § 1346(b) (Supp. V 1999); 28 U.S.C § 2674 (1994). State substantive tort law also governs federal court tort cases in which the diverse residence of private parties is the basis for federal jurisdiction (see Erie Railroad Co. v. Tompkins). Thus, the substantive law governing federal court tort actions against the federal government is substantially similar to the law governing federal court actions against private defendants.

Differences in the law governing the two classes of tort actions do exist. Unless the plaintiff's complaint alleges that at least $\$ 75,000$ is in controversy, federal courts lack jurisdiction to hear diversity cases. 28 U.S.C. $\S$ 1332(a) (Supp. V 1999). This amount was increased from $\$ 10,000$ in

1. For summary statistics about the large number of collection and enforcement actions in federal court, see Clermont and Eisenberg (1995:Appendix). 
1988 (Pub. L. 100-702, 102 Stat. 4642 (1988)), and from \$50,000 in 1996 (Pub. L. 104-317, 110 Stat. 3847 (1996)). FTCA cases are subject to a requirement that plaintiffs first present their claims to the appropriate federal agency. ${ }^{2}$ Additionally, the FTCA provides the U.S. with a defense, the discretionary function exception, which is not generally available in private tort litigation. 28 U.S.C. $§ 2680$ (a) (1994). And neither punitive damages nor jury trials are available against the U.S. under the FTCA. 28 U.S.C. $\S \S 2402,2674$ (1999). We consider below the effect of these differences on expected case outcomes.

\subsection{Job Discrimination Cases}

Our second group of cases is job discrimination cases. The bulk of employment discrimination suits are brought in federal court under Title VII of the Civil Rights Act of 1964. Most of these cases involve private plaintiffs suing private defendants. In Title VII cases, however, the United States can be present on either side of the lawsuit. The Equal Employment Opportunity Commission (EEOC) may bring Title VII actions on behalf of private litigants. 42 U.S.C. $\S 2000 \mathrm{e}-5(\mathrm{f})(1)$ (1994). And the Attorney General may sue in cases involving a pattern or practice of intentional discrimination. 42 U.S.C. $§ 2000$ e-6 (1994). Departments, agencies, and units of the United States may be, and often are, defendants in Title VII actions. 42 U.S.C. $\S 2000 \mathrm{e}-16$ (c) (1994).

The substantive legal standards governing purely private Title VII litigation are the same as the legal standards that apply when the United States appears as a defendant. 42 U.S.C. $§ 2000 e-16(c)-(d)$ (1994). Thus, Title VII cases allow one to compare the government's behavior both as a plaintiff and as a defendant with the behavior of private parties.

Some differences between legal rules that apply to government and those that apply to private litigants are again worth noting. Plaintiffs

2. 28 U.S.C. $§ 2675(a)$ (1994) states in part: "An action shall not be instituted upon a claim against the United States for money damages for injury or loss of property or personal injury or death caused by the negligent or wrongful act or omission of any employee of the Government while acting within the scope of his office or employment, unless the claimant shall have first presented the claim to the appropriate Federal agency and his claim shall have been finally denied by the agency in writing and sent by certified or registered mail. The failure of an agency to make final disposition of a claim within six months after it is filed shall, at the option of the claimant any time thereafter, be deemed a final denial of the claim for purposes of this section." 
suing either private or government defendants for discrimination must first present their claims administratively. But the agencies to which complaints must be presented differ. Plaintiffs suing the United States must first present their claims to the decision-making federal agency or unit. 42 U.S.C. $§ 2000$ e-16(c) (1994). Plaintiffs suing private defendants must first present their claims to a state equal opportunity employment commission or to the EEOC. 42 U.S.C. $§ 2000 \mathrm{e}-5$ (1994).

A statute, 42 U.S.C. $§ 1981$ (1994), under which one may sue private defendants for employment discrimination, is not available against the United States as an entity. During most of the period covered by this study, in cases of intentional discrimination, section 1981 provided a basis for blacks and other minorities, but not women, to seek compensatory and punitive damages and jury trials. These remedies were not available in Title VII actions against the United States (Eisenberg and Schwab, 1988b). ${ }^{3}$ Section 1981 also has different procedural requirements than Title VII (Eisenberg and Schwab, 1988b, p. 602 n. 38). But available evidence suggests that differences between case outcomes in Title VII and section 1981 actions are minimal (Eisenberg and Schwab, 1988b, p. 600). ${ }^{4}$ Once again, we consider the effect of these differences on expected case outcomes.

3. Two statutory developments during the period covered by this study should be noted. First, the Civil Rights Act of 1991 extended the availability of compensatory damages and jury trials to women in intentional discrimination cases against both private and governmental defendants. 42 U.S.C. $\$ 1981 \mathrm{a}(\mathrm{a})(1)-(2)$, (c) (1994). Punitive damages are still not allowed against the government. 42 U.S.C. $§ 1981 \mathrm{a}(\mathrm{b})(1)$ (1994). The Civil Rights Act of 1991 was generally effective on November 21, 1991, the date of Pub. L. No. 102-166's enactment, Pub. L. No. 102-166, § 402(a) 105 Stat. 1099 (1991), and does not apply to cases arising before its enactment. Landgraf $v$. USI Film Prods., (1994, p. 257). Second, Title I of the Americans with Disabilities Act (ADA), 42 U.S.C. $§ \S 12101-12117$ (1994), may, over time, shift the makeup of filed job discrimination cases. The ADA was enacted on July 26, 1990, and became effective two years later. Pub. L. 101-336, § 108, 104 Stat. 328 (1990). Since, as will be discussed, we limit the sample to cases filed in 1994 or earlier, the Civil Rights Act of 1991 and ADA cases should have a minor effect on our analysis, and our results do not materially differ if we limit the sample to cases filed in 1991 or earlier, thereby eliminating the effect of these statutory developments.

4. "Examining the outcome and procedural progress of section 1981 litigation reveals no distinctive pattern differentiating it from litigation under section 1983 and title VII." This is likely because of the considerable overlap between section 1981 actions and Title VII actions (Eisenberg and Schwab, 1988b, pp. 602-603). 


\section{Theoretical Framework}

In our earlier work we developed a theoretical framework to examine the effect on suit outcomes of the selection of potential claims for litigation (Eisenberg and Farber, 1997). We extend that selection model here to consider its implications for the case outcomes, given differences between the government and private parties as litigants. In this section we develop a version of this model of the litigation process that includes specifications for the expected trial outcome, the negotiated settlement, and the probability of a trial. We then use these constructs to model the plaintiff's decision regarding whether to file a lawsuit.

\subsection{The Basic Model of Case Selection}

Consider a potential plaintiff's decision regarding whether or not to file a lawsuit. Without being specific about the information structure or timing of the litigation process, we can say the suit has some expected value to the plaintiff, $E\left(V_{p}\right)$, as a function of the likelihood that the defendant would be found liable at trial $(\pi)$, the expected damages that would be awarded at trial conditional on a finding of liability $(D)$, and the costs to the plaintiff and defendant ( $C_{p}$ and $C_{d}$ respectively) of litigation. More formally, the plaintiff's expected value of filing a suit is

$$
E\left(V_{p}\right)=V_{p}\left(\pi, D, C_{p}, C_{d}\right) .
$$

The potential plaintiff will file a lawsuit if and only if $E\left(V_{p}\right) \geq 0.5$

The plaintiff's expected value of filing a lawsuit is a probability-oftrial weighted average of the expected outcome at trial and the negotiated outcome. This is

$$
E\left(V_{p}\right)=P Y_{t}+(1-P) Y_{n},
$$

where $P$ is the plaintiff's expectation about the probability of trial, $Y_{t}$ is the plaintiff's expectation of the trial outcome should a trial occur, and $Y_{n}$ is the plaintiff's expectation of the negotiated outcome should such an

5. Depending on the information structure of the game, $\pi, D$, or $C_{d}$ (or a combination) may not be known to the plaintiff, ex ante, and, if not known, it will be represented by the parameters of some prior distribution. An alternative approach to modeling litigation emphasizes asymmetric information rather than divergent expectations. See, for example, Bebchuk (1984), Daughety and Reinganum (1994), Reinganum (1982), Reinganum and Wilde (1986), Shavell (1996), and Spier (1994). 
outcome occur. We assume for simplicity that the plaintiff and defendant are risk neutral. Thus, the plaintiff's utility is $Y_{t}$ from a trial outcome and $Y_{n}$ from a negotiated outcome. The defendant's utility is $-Y_{t}$ from a trial outcome and $-Y_{n}$ from a negotiated outcome.

As a first step toward calculating the probability of trial, we derive the contract zone, which is the range of potential negotiated settlements that both parties prefer to a trial outcome. Suppose the parties have common expectations about the level of damages, $D$, but potentially divergent expectations about the likelihood of liability at trial. Let the plaintiff's and defendant's expected probability of liability be $\pi_{p}$ and $\pi_{d}$, respectively. These expectations can be written as

$$
\pi_{p}=\pi+\theta_{p}
$$

and

$$
\pi_{d}=\pi+\theta_{d},
$$

where $\pi$ is the common component of the probability of liability and $\theta_{p}$ and $\theta_{d}$ are the plaintiff's and defendant's idiosyncratic components of the expected probability of liability. The idiosyncratic components are assumed to have zero mean and to be uncorrelated with other characteristics. ${ }^{6}$

The plaintiff expects a net value from trial of $\pi_{p} D-C_{p}$, and the plaintiff will accept no less than this as a negotiated settlement. Analogously, the defendant expects a net loss from trial of $\pi_{d} D+C_{d}$, and the defendant will pay no more than this as a negotiated settlement. Thus, the contract zone is defined by

$$
\pi_{p} D-C_{p} \leq Y_{n} \leq \pi_{d} D+C_{d},
$$

and the size of the contract zone is

$$
\begin{aligned}
C Z & =\left(\pi_{d}-\pi_{p}\right) D+\left(C_{p}+C_{d}\right) \\
& =\left(\theta_{d}-\theta_{p}\right) D+\left(C_{p}+C_{d}\right) .
\end{aligned}
$$

Note that size of the contract zone does not depend on the common component of the probability of liability $(\pi)$, but it is directly related to the

6. Note that the parties know only their expectations $\left(\pi_{p}\right.$ and $\left.\pi_{d}\right)$ and cannot parse these into the common component $(\pi)$ and their idiosyncratic components $\left(\theta_{d}\right.$ and $\left.\theta_{p}\right)$. 
difference between the defendant's and plaintiff's idiosyncratic components $\left(\theta_{d}-\theta_{p}\right)$.

We assume that a necessary and sufficient condition for a negotiated settlement is that the size of the contract zone is weakly positive. Trial outcomes occur only when $C Z<0$, and this happens only when expectations are relatively optimistic $\left(\pi_{p}>\pi_{d}\right.$ or $\left.\theta_{p}>\theta_{d}\right)$. If expectations are identical or relatively pessimistic $\left(\pi_{p} \leq \pi_{d}\right.$ or $\left.\theta_{p} \leq \theta_{d}\right)$, then positive aggregate costs are sufficient to guarantee $C Z \geq 0$ and a negotiated settlement. ${ }^{7}$ It is clear from equation (7) that, for any degree of divergent expectations, higher total costs of disagreement $\left(C_{p}+C_{d}\right)$ make it more likely that there will be a positive contract zone. This is a basis for the claim that higher costs of disagreement lead to more negotiated settlements and fewer disputes (trials).

The property of the model that a trial occurs if $C Z<0$ can be used to derive the ex ante probability of trial from the plaintiff's perspective. The plaintiff knows $\pi_{p}$, but we assume that the plaintiff does not know $\pi_{d}$. However, the plaintiff knows that $\pi_{d}$ is drawn from a distribution with cumulative distribution function $F(\cdot)$. The condition for a trial, $C Z<0$, can be written, on rearrangement of equation (6), as

$$
\pi_{d}<\pi_{p}-\frac{C_{p}+C_{d}}{D}
$$

so that the probability of a trial is

$$
P=F\left(\pi_{p}-\frac{C_{p}+C_{d}}{D}\right) .
$$

This implies that trials are more likely where $\pi_{p}$ and $D$ are higher and where $C_{p}$ and $C_{d}$ are lower.

The final quantity needed to compute $E\left(V_{p}\right)$ is the plaintiff's expectation of the negotiated outcome should such an outcome occur. In order to compute this expectation, a specific solution to the bargaining problem is required, and, as is commonly done in the applied economics literature on bargaining, we rely on the Nash solution. ${ }^{8}$ Central to the Nash solution

7. See Farber and Bazerman (1987, 1989), Farber and Katz (1979), Gould (1973), Landes and Posner (1979), and Posner (1973) for discussions of divergent expectations as an explanation for disagreements leading to arbitration or litigation.

8. The solution to the Nash bargaining problem is the outcome that satisfies a set of four axioms (Pareto optimality, symmetry, independence of irrelevant alternatives, and insensitivity to linear transformations of utility). See Nash (1950). The general character of results is likely to be supported by the solution to a wide range of bargaining models. 
are the threat points of the parties. These are the payoffs to the parties in the event that they do not agree on a negotiated settlement, and they are expressed here as the expected trial outcome net of costs. If the parties do not agree on a negotiated settlement, the expected trial outcome is to award $\pi_{p} D$ to the plaintiff. This expected trial outcome yields a payoff to the plaintiff net of costs of $\pi_{p} D-C_{p}$ and yields a payoff to the defendant net of costs of $-\pi_{p} D-C_{d} \cdot{ }^{9}$ These expected payoffs from a trial outcome are the threat points of the Nash bargaining model.

In order to derive the Nash solution, first compute for each party the difference between the payoff from the negotiated settlement and the payoff at trial net of costs. The payoffs at trial net of costs are the threat point payoffs, and these differences are the net gains from a negotiated settlement relative to receiving the threat point payoffs. The Nash solution to the bargaining problem is derived as the value of $Y_{n}$ that maximizes the product of the net gains from a negotiated settlement. This is

$$
W=\left(Y_{n}-\left(\pi_{p} D-C_{p}\right)\right) \cdot\left(-Y_{n}-\left(-\pi_{p} D-C_{d}\right)\right) .
$$

The solution to this maximization problem yields a negotiated settlement of

$$
Y_{n}=\pi_{p} D+\frac{\left(C_{d}-C_{p}\right)}{2},
$$

which is the negotiation payoff to the plaintiff. Note that $Y_{n}$ is positively related to the expected trial outcome $\left(\pi_{p} D\right)$ and the defendant's costs $\left(C_{d}\right)$ and negatively related to the plaintiff's costs $\left(C_{p}\right)$.

Now consider the plaintiff's decision regarding whether to file a lawsuit in the case in which the negotiated settlement is as defined in equation (11). In fact, there may not be a negotiated settlement, and the case

9. Note that using this payoff to the defendant in forming the plaintiff's expectation regarding the Nash bargaining solution implies that the potential plaintiff ignores any information there might be in the fact that the parties cannot agree on a negotiated settlement (i.e., that $C Z<0$ ) and assumes that the defendant has the same probability of liability as the plaintiff $\left(\pi_{p}\right)$. This was done to keep the mathematical exposition relatively clear. At least two alternatives to this assumption are possible. First, the plaintiff might realize, in the event that no negotiated settlement is reached, that expectations are sufficiently relatively optimistic to cause $C Z<0$. This would mean that $\pi_{d}<\pi_{p}-\frac{C_{p}+C_{d}}{D}$ and would affect the plaintiff's expectation of the defendant's threat point. Second, the plaintiff might use the unconditional expectation of $\pi_{d}$ based on $F(\cdot)$. Neither of these alternatives changes the basic character of the theoretical results. 
may go to trial, yielding a net trial payoff to the plaintiff as noted above of

$$
Y_{t}=\pi_{p} D-C_{p}
$$

This too is positively related to the expected trial outcome and negatively related to the plaintiff's costs, but it is unrelated to the defendant's costs.

Using the Nash solution in equation (11) as the negotiated settlement and using the net trial payoff in equation (12), the plaintiff's expected value for the lawsuit is

$$
\begin{aligned}
E\left(V_{p}\right) & =(1-P)\left[\pi_{p} D+\frac{C_{d}-C_{p}}{2}\right]+P\left[\pi_{p} D-C_{p}\right] \\
& =\left(\pi+\theta_{p}\right) D+\frac{C_{d}-C_{p}}{2}-P \frac{C_{d}+C_{p}}{2} .
\end{aligned}
$$

Holding $P$ fixed, it is straightforward to demonstrate, based on equation (14), that $E\left(V_{p}\right)$ is increasing in $\pi, \theta_{p}, D$, and $C_{d}$ and decreasing in $C_{p}$. However, the case characteristics (with the exception of $\pi$ ) affect $P$ as well, and this makes it more difficult to ascertain the direction of their effects on $E\left(V_{P}\right)$. Specifically,

$$
\begin{aligned}
& \frac{\partial E\left(V_{p}\right)}{\partial \theta_{p}}=D-\frac{\partial P}{\partial \theta_{p}}\left[\frac{C_{d}+C_{p}}{2}\right] ; \\
& \frac{\partial E\left(V_{p}\right)}{\partial D}=\pi_{p}-\frac{\partial P}{\partial D}\left[\frac{C_{d}+C_{p}}{2}\right] ; \\
& \frac{\partial E\left(V_{p}\right)}{\partial C_{p}}=-\frac{(1+P)}{2}-\frac{\partial P}{\partial C_{p}}\left[\frac{C_{d}+C_{p}}{2}\right] ; \\
& \frac{\partial E\left(V_{p}\right)}{\partial C_{d}}=\frac{(1-P)}{2}-\frac{\partial P}{\partial C_{d}}\left[\frac{C_{d}+C_{p}}{2}\right] .
\end{aligned}
$$

Since $\frac{\partial P}{\partial \theta_{p}}$ and $\frac{\partial P}{\partial D}$ are positive and $\frac{\partial P}{\partial C_{p}}$ and $\frac{\partial P}{\partial C_{d}}$ are negative, only $\frac{\partial E\left(V_{p}\right)}{\partial C_{d}}$ can be signed unambiguously (positive). The direct effects of increases in $\pi, \theta_{p}$ and $D$ are, not surprisingly, positive as increasing the plaintiff's expected trial outcome increases the expected value of filing suit. But increasing the plaintiff's expected trial outcome (through an increase in $\theta_{p}$ or $D$ ) also increases the probability of trial, which has a negative effect on the expected value of filing suit. Similarly, the direct effect of an increase in the plaintiff's costs is to decrease the expected value of filing suit, but the increase in plaintiff's costs decreases the probability of trial, which has a positive effect on the expected value of filing suit. An increase in 
the defendant's costs has a positive direct effect on the plaintiff's expected value of filing suit, an effect that is reinforced by the implied decrease in the probability of trial.

We proceed with the reasonable assumption that the effects of the implied changes in the probability of trial are not sufficiently large to offset the direct effects. This implies that the plaintiff's expected value from filing suit is increasing in $\pi, \theta_{p}, D$, and $C_{d}$ and decreasing in $C_{p}$. Thus, plaintiffs are more likely to file suit where $\pi, \theta_{p}, D$, and $C_{d}$ are higher and where $C_{p}$ is lower.

\subsection{Implications of the Model for Trial Rates}

The data contain information for filed cases on whether or not the case was decided through a trial and whether or not the plaintiff won at trial. ${ }^{10}$ Equation (9) expresses the ex ante probability of a trial from the plaintiff's perspective, $P$. However, from the analyst's perspective, the ex post probability of a trial in cases in which a lawsuit has been filed is

$$
\begin{aligned}
T & =\operatorname{Pr}\left[\left(\pi_{p}-\pi_{d}\right) D-\left(C_{p}+C_{d}\right)>0 \mid E\left(V_{p}\right)>0\right] \\
& =\operatorname{Pr}\left[\left(\theta_{p}-\theta_{d}\right) D-\left(C_{p}+C_{d}\right)>0 \mid E\left(V_{p}\right)>0\right]
\end{aligned}
$$

where $E\left(V_{p}\right)$ is defined in equation (12) as a function of $\pi, \theta_{p}, D, C_{p}$, and $C_{d}$.

Without considering the systematic selection of cases for litigation, the probability of trial is unrelated to the common component of the probability of liability $(\pi)$, positively related to the stakes $(D)$, and negatively related to each party's costs of litigation $\left(C_{p}\right.$ and $\left.C_{d}\right)$. However, consideration of the selection process modifies these predictions.

There is no direct effect of the common component of the probability of liability $(\pi)$ on the probability of trial, but there is an indirect effect through the selection process. The plaintiff's expected value of filing suit $\left(E\left(V_{p}\right)\right)$ is positively related to $\pi$. This implies that an increase in $\pi$ will make it optimal to file suit in cases in which the plaintiff's idiosyncratic information about the probability of liability $\left(\theta_{p}\right)$ is lower, in which plaintiff's costs are higher, in which defendant's costs are lower, and in which

10. More precisely, there is information on whether or not judgment was entered for the plaintiff after trial. We discuss below potential problems in interpreting this information as indicating a plaintiff win. 
the stakes are lower. With the exception of the decrease in defendant's costs, all of these changes in the composition of cases filed imply that the trial rate will be lower where the common component of the probability of liability is higher.

The direct effect of the stakes $(D)$ on the trial rate is positive, but the indirect effect through the case selection process offsets this to some extent. The plaintiff's expected value of filing suit $\left(E\left(V_{p}\right)\right)$ is positively related to $D$. This implies that an increase in $D$ will make it optimal to file suit in cases in which the plaintiff's information about the probability of liability $\left(\pi\right.$ and $\left.\theta_{p}\right)$ are lower, in which plaintiff's costs are higher, and in which defendant's costs are lower. With the exception of the decrease in defendant's costs, all of these selection-induced changes in the composition of cases filed imply that the trial rate will be lower where the stakes are higher, weakening the direct effect.

The direct effect of plaintiff's costs $\left(C_{p}\right)$ on the trial rate is negative, but there is an offsetting effect through the case selection process. $E\left(V_{p}\right)$ is negatively related to $C_{p}$. This implies that an increase in $C_{p}$ will make it optimal to file suit in cases in which the plaintiff's information about the probability of liability $\left(\pi\right.$ and $\theta_{p}$ ) is more favorable, in which the stakes are higher, and in which defendant's costs are higher. With the exception of the increase in defendant's costs, all of these selection-induced changes in the composition of cases filed imply that the trial rate will be higher where the plaintiff's costs of litigation are higher, weakening the direct effect.

The direct effect of defendant's costs $\left(C_{d}\right)$ on the trial rate is negative, and the effect through the selection process reinforces the direct effect. $E\left(V_{p}\right)$ is positively related to $C_{d}$. This implies that an increase in $C_{d}$ will make it optimal to file suit in cases in which the plaintiff's information about the probability of liability $\left(\pi\right.$ and $\theta_{p}$ ) is less favorable, in which the stakes are lower, and in which plaintiff's costs are higher. All of these selection-induced changes in the composition of cases filed imply that the trial rate will be lower where the defendant's costs of litigation are higher, reinforcing the direct effect.

The first three columns of Table 1 contain a summary of the predictions of the model with regard to the relationships between the trial rate and case characteristics. The predictions are unambiguously negative with regard to the effects of $\pi$ and $C_{d}$ on the trial rate. But there are not clear predictions 
Table 1. Summary of Predictions of Selection Model for Trial Rates and Plaintiff Win Rates at Trial by Case Characteristic

\begin{tabular}{lccccccc}
\hline & \multicolumn{3}{c}{ Trial Rate } & & \multicolumn{3}{c}{ Win Rate } \\
\cline { 2 - 4 } \cline { 8 - 9 } Parameter & Direct & Selection & Overall & & Direct & Selection & Overall \\
\hline$\pi$ & 0 & - & - & & + & + & + \\
$D$ & + & - & & & 0 & - & - \\
$C_{p}$ & - & + & & & 0 & + & + \\
$C_{d}$ & - & - & - & & 0 & - & - \\
\hline
\end{tabular}

with regard to the effects of $D$ and $C_{p}$ on trial rates, because the direct and selection effects are offsetting. However, if we assume that the direct effects dominate, then the trial rate is positively related to $D$ and negatively related to $C_{p}$.

\subsection{Implications of the Model for Plaintiff Win Rates at Trial}

The model has implications for how plaintiff win rates at trial vary with the parties' litigation costs by means of the case selection process. We represent the probability that the defendant is liable at trial as

$$
\pi_{t}=\pi+\theta_{t},
$$

where $\pi$ is the common component of the probability of liability and $\theta_{t}$ is a random component with zero mean that is uncorrelated with case characteristics or with the plaintiff's or defendant's idiosyncratic component of the probability of liability $\left(\theta_{p}\right.$ and $\left.\theta_{d}\right)$. The observed win rate at trial is the expectation of $\pi_{t}$, conditioned on both a case's being filed and the case's being decided at trial. This is

$$
\begin{aligned}
E\left(\pi_{t}\right) & =E\left[\pi+\theta_{t} \mid E\left(V_{p}\right)>0,\left(\theta_{p}-\theta_{d}\right) D-\left(C_{p}+C_{d}\right)>0\right] \\
& =E\left[\pi \mid E\left(V_{p}\right)>0,\left(\theta_{p}-\theta_{d}\right) D-\left(C_{p}+C_{d}\right)>0\right],
\end{aligned}
$$

where the first conditioning event is that the claim is filed as a lawsuit and the second conditioning event is that the case was decided at trial. The second equality follows from the fact that $\theta_{t}$ has zero mean and is uncorrelated with case characteristics so that its conditional expectation is also zero. The probability of a trial (the second conditioning event) does not depend directly on the common information on the probability of liability $(\pi)$. Thus, the effect of selection on case characteristics is 
due to the plaintiff's decision regarding whether to file a lawsuit. Case characteristics will affect the plaintiff win rate to the extent that they affect the distribution of $\pi$ by means of the selection process.

Higher values of plaintiff's costs imply that the minimum threshold value of $\pi$ at which potential plaintiffs decide to file lawsuits will increase, ceteris paribus. Thus, plaintiff win rates at trial will be higher where plaintiff's costs are higher. Higher stakes and higher defendant's costs imply the opposite. The minimum threshold value of $\pi$ at which potential plaintiffs decide to file lawsuits will decrease where the stakes or defendant costs are higher, ceteris paribus. Thus, plaintiff win rates at trial will be lower where the stakes or defendant's costs are higher. These predictions are summarized in the last three columns of Table 1.

One potential complication is that the expected outcome of the case $(\pi D)$ may affect the costs of litigation. It may be optimal for the parties to spend more to pursue or defend high-expected-outcome cases. Thus, there is a direct effect of the expected outcome on the case selection decision, and there is an indirect effect through the costs. The indirect effect through the defendant's costs works in the same direction as the direct effect of the stakes. Higher expected outcomes and higher defendant costs yield a higher $E\left(V_{p}\right)$, which implies that potential plaintiffs will be more likely to file suit. But the indirect effect through the plaintiff's costs works in the opposite direction. Higher plaintiff's costs reduce the likelihood that the potential plaintiff will decide to file a suit. We assume that the direct effect dominates so that an increase in the expected stakes will never raise plaintiff's costs so much that the plaintiff becomes less likely to file suit.

Our analysis has implications for how case outcomes (trial rates and plaintiff win rates) with the federal government as a party differ from case outcomes with two private parties. These implications are derived from institutional and legal differences between cases with the two types of parties, differences with regard to the probability of liability $(\pi)$, the stakes of the case $(D)$, and the litigation costs $\left(C_{p}\right.$ and $\left.C_{d}\right)$.

\section{The Government as Defendant: Tort Claims}

Consider a private plaintiff who is deciding whether or not to file suit in a particular case. This decision will be based on the value of $E\left(V_{p}\right)$ as described in equations (1) and (2). The difference between cases in 
which the potential defendant is the government and those in which the potential defendant is a private party depends on how tort litigation with the government and private parties differ with regard to litigation costs $\left(C_{d}\right.$ and $\left.C_{p}\right)$ and the components of expected damages $(\pi$ and $D)$.

With regard to defendants' costs, it is plausible that the government's costs, both quantifiable and the broader, more subjective aspect of costs already noted, differ from those of private litigants. We suspect that, on average, the federal government is less fearful of litigation than are private litigants. Government is, after all, as permanent a secular institution as we have and has been litigating for hundreds of years. Litigation to enforce laws and defend against attacks on laws and government policies is part of its routine. Government is so large relative to most other litigants that it, more than the average litigant, knows substantial litigation will be a part of its existence. For private litigants, especially individuals and smaller companies, litigation is unusual, almost always unwelcome, and stressful. People are quite averse to litigation (Danzon, 1985; Hensler et al., 1991; Report of the Harvard Medical Practice Study, 1990). In addition, the government does not face bet-the-company cases, which might reduce a private firm's taste for litigation. And the government, which need not trade in the private market, may respond to inputs less quantifiable than profit maximization (Eisenberg and Schwab, 1988a, p. 750).

It is also plausible, but not certain, that the government's defense costs are, on average, lower than those of private defendants in similar cases. Because of its continuing existence and repeated actions, government repeatedly defends lawsuits and presumably learns from experience, thereby lowering its relative costs (Eisenberg and Schwab, 1988a, p. 751). Some government officials may specialize in litigating a particular class of disputes (Eisenberg and Schwab, 1988a, p. 751). On average, private litigants are less likely to have such specialization. The federal government, unlike many private defendants, often has lawyers available to defend it in litigation. It often does not need to retain counsel on an hourly or contingent basis to defend the action. Of course, many private litigants may have counsel available, but not all will have such access to the extent the government does. We thus believe that the government, on average (though not in every case), has lower litigation costs than do private defendants. ${ }^{11}$

11. Although we think traditional costs and less quantifiable cost factors are lower for the government, that assumption is not necessary to support exploring whether 
Based on our selection model, as summarized in Table 1, this suggests that the trial rate will be higher and the plaintiff win rate will be higher in tort cases in which the government is defendant relative to cases with a private party as defendant.

But the difference in costs is not the only contrast between cases with a private defendant and cases with the government as defendant. Earlier we noted differences between the law governing FTCA cases against the United States and private diversity-based tort actions, differences that can affect the components of expected damages. We address five differences in tort litigation: (1) a jurisdictional amount limitation, (2) punitive damages, (3) the availability of jury trial, (4) the discretionary function exception under the FTCA, and (5) exhaustion of remedies.

The jurisdictional amount limitation for diversity cases means that federal courts see a select group of state-law-based personal injury tort cases. Only those cases with more than $\$ 75,000$ (\$50,000 before 1996 and $\$ 10,000$ before 1988) in controversy are eligible for federal litigation, thus limiting federal courts to big diversity cases. One thus expects federal court diversity cases to differ from the mass of tort cases in the amount at stake. ${ }^{12}$ The low-stakes cases are not similarly trimmed in FTCA actions. Since there is no jurisdictional amount limitation in FTCA cases, a group of low-stakes cases may be filed against the United States in federal court that cannot be filed against private parties accused of the same behavior. The inability to recover punitive damages further lowers the stakes in FTCA cases compared with diversity cases. ${ }^{13}$

the government as litigant differs from private litigants. Those who believe government costs to be higher or the same as the costs of private parties would merely predict effects opposite to those we predict, or predict no effects. Regardless of one's assumptions about the government's attitude towards litigation as compared to that of private parties, exploring whether government litigation is in fact descriptively different is worthwhile.

12. This turns out to be the case, with federal court diversity tort cases having much higher mean and median recoveries than tort cases adjudicated in state court, where there is no minimum-damage threshold. (Eisenberg et al., 1996, p. 439). Tabulation of amounts awarded to winning plaintiffs in federal court also show somewhat higher mean and median awards in diversity cases, relative to FTCA cases.

13. Available data suggest, however, that punitive damages are very rarely awarded in personal injury tort litigation, so the jurisdictional amount limitation is probably the dominant effect on stakes (Daniels and Martin, 1995; Eisenberg et al., 1997, pp. 63337; Moller, 1996; U.S. Bureau of Justice Statistics, 1995, p. 6.). 
It is not clear how the unavailability of jury trials against the United States affects the composition of cases filed relative to cases brought against private parties. It may be that the possibility of a jury trial leads plaintiffs to file cases with low probability of winning $(\pi)$ but possibly high awards $(D)$ in those cases they do win (e.g., Clermont and Eisenberg, 1992, pp. 1140-43; Salop and White, pp. 1018-19). The effect of this on expected returns $(\pi D)$ is ambiguous.

Nor is it clear how the discretionary function defense available to the United States under the FTCA will affect the composition of cases. This defense embodies the principal that "it is not a tort to govern" and thus gives the government leeway to make the decisions necessary to govern without being subjected to tort liability when discretionary decisions do not work out. ${ }^{14}$ On the one hand, this added defense available to the government may reduce the probability of a plaintiff win against the government as compared to the probability of a plaintiff win against a private party. On the other hand, since private parties do not face the range of decisions that governments face, the discretionary function exception may narrow the differences in the subject matters of private and FTCA actions. ${ }^{15}$

Finally, the requirement that plaintiffs in actions against the government exhaust administrative remedies before filing suit serves to narrow the difference between cases against the government under the FTCA and diversity cases against private parties. The exhaustion-of-remedies requirement likely increases the costs of plaintiffs in government-defendant cases compared with the costs of plaintiffs in private-defendant cases.

Overall, our analysis of how the legal differences between suits filed against the government under the FTCA and diversity cases with private defendants concludes that cases filed against the government have, on average, lower defendant costs, lower stakes, and higher plaintiff's costs. ${ }^{16}$

14. For example, Bergh v. Washington (p. 812; concurring opinion).

15. The discretionary function exception creates a rather fine line. Compare Berkovitz v. United States (discretionary function exception did not protect United States in action based on allegedly wrongful licensing and release of vaccine) with United States v. Gaubert (discretionary function exception may protect operational- or management-level decisions by regulatory bodies that became involved in the day-today operation of a savings and loan association).

16. Concern for reputation may differ between government and private defendants, as might incentives for lawyers. Although our model is not rich enough to examine 
Table 2. Summary of Predictions of Selection Model for Trial Rates and Plaintiff Win Rates at Trial: Differences between Government and Private Parties

\begin{tabular}{lccc}
\hline Type of Case & Government Role & Trial Rate & Plaintiff Win Rate \\
\hline Personal injury & Defendant & Gov $>$ Priv & Gov $>$ Priv \\
Job discrimination & Defendant & Gov $>$ Priv & Gov $>$ Priv \\
Job discrimination & Plaintiff & Gov $<$ Priv & Gov $>$ Priv \\
\hline
\end{tabular}

Using the selection model summarized in Table 1, we see that the lower stakes and higher plaintiff's costs have ambiguous effects on the trial rate, but the lower defendant costs imply a higher trial rate in cases against the government. There is no such ambiguity with regard to the plaintiff win rate at trial. The selection model predicts that the lower stakes, higher plaintiff's costs, and lower defendant costs will result in higher plaintiff win rates at trial when the government is defendant. These predictions are summarized in the first row of Table 2.

\section{The Government in Job Discrimination Cases}

\subsection{The Government as Defendant}

As in tort cases, we assume that the government's defense costs in job discrimination cases are, on average, lower than private defendants' costs. Donohue and Siegelman (1993, p. 728) observe that "federal officials are likely to be far less sensitive to the cost of potential Title VII damages awards than private employers are." And, as before, we predict higher trial rates in cases involving the United States as defendant and higher plaintiff win rates. It is again necessary to account for differences in legal rules applicable to government and private defendants.

Government and private defendants operate under somewhat different rules in job discrimination cases, though the differences are not as great as in tort cases. Perhaps the most important difference is the lack of an

reputation's role, if reputational factors are more important to the government, the case selection process should yield a stronger set of plaintiff claims against the government than against private defendants. Our selection model implies that a stronger set of filed cases (higher $\pi$ ) implies a lower trial rate and a higher plaintiff win rate at trial. 
alternative statutory remedy against the United States for job discrimination. The alternative remedy against private parties for job discrimination, available under 42 U.S.C. $\S 1981$, gave black plaintiffs a chance for compensatory and punitive damages against private defendants. ${ }^{17}$ Since such damages are not available against the United States, the stakes $(D)$ are lower in job discrimination cases with the government as defendant, relative to private-defendant cases.

Our analysis of how the legal differences between job discrimination suits filed against the government differ from job discrimination suits filed against private defendants suggests that cases filed against the government have, on average, lower defendant costs and lower stakes. Using the selection model summarized in Table 1, we see that the lower stakes have ambiguous effects on the trial rate, but the lower defendant costs imply a higher trial rate in cases against the government. The model has a clear prediction with regard to the plaintiff win rate at trial. The selection model predicts that the lower stakes and lower defendant costs will result in higher plaintiff win rates at trial when the government is defendant. These predictions are summarized in the second row of Table 2.

\subsection{The Government as Plaintiff}

Job discrimination is the only subject matter area for which we have data, for which both the government and private parties frequently appear as plaintiffs, and for which the law applicable to the government is substantially similar to the law applicable to private parties. ${ }^{18}$ But there are differences.

Job discrimination cases in which the government appears as plaintiff have gone through an elaborate screening process. The EEOC chooses, from among the thousands of complaints filed with it, which complaints to convert to lawsuits brought in its own name. It is not clear to us that the government as plaintiff has lower mean financial costs than private job discrimination plaintiffs, but the decision to file suit likely differs between

17. After 1991, the Civil Rights Act of 1991 made such damages available to female plaintiffs suing private parties. But our results do not materially differ if we limit the sample to cases filed in 1991 and earlier. See note 3.

18. The other class of cases in which we study the government as defendant, personal injury tort cases, does not contain cases in which the government appears as plaintiff. The government does not suffer personal injuries in the way that private individuals do and so does not appear as a plaintiff in personal injury tort actions. 
the EEOC and private plaintiffs. Presumably, the EEOC screens cases carefully and makes litigation choices based on the economic merits of the case. But the class of individuals who bring job discrimination cases is dominated by people who have lost their jobs (Donohue and Siegelman, 1991, p. 984). These private plaintiffs in job discrimination cases are, on average, those job-losers with the lowest costs of litigation, where costs of litigation are defined broadly to include pecuniary as well as (perhaps negative) nonpecuniary costs.

On this basis, a crude characterization of the government's case selection process in job discrimination cases is that the government selects "high quality" cases, that is, cases with a relatively high probability of plaintiff victory (high $\pi$ ). In contrast, the selection process of private plaintiffs in job discrimination cases is more likely to depend on relatively low litigation costs (low $C_{p}$ ), often nonpecuniary, that come from the experience of a job loss. ${ }^{19}$

The selection model, summarized in Table 1, implies that the higher value of $\pi$ in discrimination cases brought by the government will result in a lower trial rate. The higher effective costs to the government as plaintiff have a negative direct effect on the trial rate, which is offset to some extent by a positive selection effect. The higher values of $\pi$ and of $C_{p}$ both imply unambiguously higher plaintiff win rates at trial. These predictions are summarized in the last row of Table 2 .

\section{The Data}

The data used here were gathered by the Administrative Office of the U.S. Courts and the Federal Judicial Center. ${ }^{20}$ When any civil case terminates in federal district court, the court clerk transmits to the Administrative Office a form containing information about the case. The form includes data regarding the subject matter of the case, removal status, the amount demanded, the dates of filing and termination, the procedural progress of the case at termination, the method of disposition, and, when a judgment has been entered, who prevailed and any amount awarded in

19. In other areas of law plaintiffs in employment cases also fare unusually poorly (Hillman, 1998, pp. 583, 591-93).

20. For a fuller description of the database, see Clermont and Eisenberg (1992, pp. 1133-34). 
damages. The form distinguishes among many subject matter categories, including branches of contract, tort, and other areas of law. The form distinguishes among several areas of personal injury tort law. It also contains a category labeled "job discrimination" that includes Title VII cases, section 1981 cases, and cases from other branches of antidiscrimination employment law.

For present purposes, a key aspect of the data is that it indicates the jurisdictional basis for each case's presence in federal court. Four bases of federal jurisdiction are relevant: (1) the United States is a plaintiff, (2) the United States is a defendant, (3) the case involves a federal question, one arising under the Constitution or laws of the United States, and (4) the case arises under state law but involves parties who are citizens of different states, the so-called diversity jurisdiction.

By using the subject matter of the cases and the basis for jurisdiction, we can identify personal injury tort cases against the United States, and personal injury tort cases based on diversity jurisdiction. Further, we can distinguish job discrimination cases brought by and against the United States from job discrimination cases brought by and against other parties. $^{21}$

We create two samples from these data. Our first sample contains all personal injury cases filed in federal court between July 1, 1979, and September 30, 2000, based on diversity jurisdiction or with the government as defendant. This sample contains 480,765 cases, comprising 423,600 diversity cases and 57,165 cases with the government as defendant. $^{22}$ Our second sample contains all job discrimination cases filed in federal court over the same period. This sample contains 272,156 cases,

21. A portion, presumably small, of the job discrimination cases treated here as private-defendant cases are in fact filed against state governments, and we have no way to separate those cases out. 42 U.S.C. § 2000e(a) (1994). The tort cases we consider do not include actions against states. The Eleventh Amendment prohibits state-lawbased tort actions from being brought against states in federal court. See Welch v. State Dep't of Highways and Public Transp. (Jones Act); Florida Dep't of State v. Treasure Salvors, Inc. (admiralty cases).

22. We deleted all personal injury cases filed in two of the 91 federal districts (a total of 12,381 cases) because there was one year in each district for which an unusually large number of tort claims were filed in a single month, claims that have not been resolved despite their being pending for six years in one district and for 13 years in the other. See our discussion, below, of the analytical difficulties raised by unresolved cases. 
comprising 243,665 cases involving only private parties, 19,673 cases with the government as defendant, and 8,818 cases with the federal government as plaintiff.

Since our data end with the close of the 2000 federal government fiscal year, we have no data on case progress after September 30, 2000. Thus, any cases not resolved by that date are censored in the sense that their outcomes are not observed. Of the 480,765 personal injury cases filed between July 1979 and September 2000, 457,482 were resolved and 23,283 were not resolved in time for the resolution to be recorded in our data. Of the 272,156 job discrimination cases filed between July 1979 and September 2000, 243,866 were resolved and 24,290 were not resolved in time for the resolution to be recorded in our data. This censoring is an important statistical problem in the analysis of trial rates and outcomes because cases that proceed to trial are likely to take substantially longer to resolve than cases that are dropped or settled without a trial verdict. Thus, tried cases will be censored disproportionately.

Table 3 shows the number of cases in our sample filed in each calendar year by category of case. ${ }^{23}$ Table 3 also shows the fraction of cases pending as of September 30, 2000, by year of filing. Overall, about $5 \%$ of the personal injury cases and $9 \%$ of the job discrimination cases in our samples are censored, and it is clear that cases filed more recently are much more likely to be censored.

That this censoring is an important problem is apparent from the tabulations of the fraction of cases tried by year of filing, as contained in Table 3. This fraction is computed as the fraction of resolved cases for which there was a trial verdict. The trial rate computed this way falls dramatically with the year of filing. This does not represent purely a real decline in trial rates and is in large part an artifact of the decline in time until the censoring date, with the concomitant lack of time for cases that will ultimately be tried to reach a trial verdict.

A straightforward approach to the censoring problem is to use only cases filed long enough before 2000 that the censoring problem

23. The number of cases filed in 1979 is about half of the number in the immediately succeeding years, because we exclude cases filed before July 1, 1979. This date marks the beginning of the data's inclusion of the party for whom judgment was entered. Similarly, the number of cases filed in 2000 is about three-fourths the number of cases filed in the immediately preceding years, because we have no data on cases filed after September 30, 2000. 
Table 3. Case Distribution and Resolution by Year of Filing

\begin{tabular}{|c|c|c|c|c|c|c|}
\hline \multirow[b]{2}{*}{$\begin{array}{l}\text { Year } \\
\text { Filed }\end{array}$} & \multicolumn{3}{|c|}{ Personal Injury Cases } & \multicolumn{3}{|c|}{ Job Discrimination Cases } \\
\hline & $\begin{array}{l}\text { Number } \\
\text { of Cases }\end{array}$ & $\begin{array}{l}\text { Fraction } \\
\text { Pending }\end{array}$ & $\begin{array}{c}\text { Fraction } \\
\text { Tried }\end{array}$ & $\begin{array}{l}\text { Number } \\
\text { of Cases }\end{array}$ & $\begin{array}{l}\text { Fraction } \\
\text { Pending }\end{array}$ & $\begin{array}{c}\text { Fraction } \\
\text { Tried }\end{array}$ \\
\hline 1979 & 7,003 & 0.0000 & 0.0824 & 2,432 & 0.0000 & 0.1727 \\
\hline 1980 & 14,197 & 0.0000 & 0.0976 & 5,491 & 0.0004 & 0.1620 \\
\hline 1981 & 11,934 & 0.0000 & 0.0920 & 7,049 & 0.0000 & 0.1644 \\
\hline 1982 & 12,783 & 0.0000 & 0.0942 & 8,324 & 0.0002 & 0.1508 \\
\hline 1983 & 12,317 & 0.0000 & 0.0911 & 10,027 & 0.0002 & 0.1326 \\
\hline 1984 & 11,858 & 0.0001 & 0.0957 & 8,493 & 0.0001 & 0.1229 \\
\hline 1985 & 17,808 & 0.0001 & 0.0708 & 8,660 & 0.0001 & 0.1172 \\
\hline 1986 & 23,948 & 0.0000 & 0.0610 & 9,130 & 0.0001 & 0.1037 \\
\hline 1987 & 25,316 & 0.0002 & 0.0619 & 8,493 & 0.0002 & 0.0954 \\
\hline 1988 & 28,641 & 0.0001 & 0.0492 & 8,674 & 0.0001 & 0.0936 \\
\hline 1989 & 28,717 & 0.0001 & 0.0450 & 8,380 & 0.0002 & 0.0859 \\
\hline 1990 & 25,727 & 0.0002 & 0.0489 & 8,122 & 0.0006 & 0.0825 \\
\hline 1991 & 23,080 & 0.0002 & 0.0482 & 9,115 & 0.0003 & 0.0765 \\
\hline 1992 & 24,864 & 0.0001 & 0.0459 & 11,205 & 0.0003 & 0.0736 \\
\hline 1993 & 28,614 & 0.0007 & 0.0387 & 13,500 & 0.0016 & 0.0711 \\
\hline 1994 & 27,774 & 0.0015 & 0.0392 & 16,524 & 0.0030 & 0.0611 \\
\hline 1995 & 32,148 & 0.0080 & 0.0356 & 20,443 & 0.0050 & 0.0516 \\
\hline 1996 & 28,947 & 0.0231 & 0.0377 & 22,910 & 0.0100 & 0.0448 \\
\hline 1997 & 29,586 & 0.0666 & 0.0337 & 24,172 & 0.0300 & 0.0390 \\
\hline 1998 & 24,875 & 0.1003 & 0.0297 & 23,368 & 0.0966 & 0.0294 \\
\hline 1999 & 24,619 & 0.2701 & 0.0166 & 22,442 & 0.3617 & 0.0174 \\
\hline 2000 & 16,009 & 0.6969 & 0.0033 & 15,202 & 0.8396 & 0.0086 \\
\hline Total & 480,765 & 0.0484 & 0.0510 & 272,156 & 0.0893 & 0.0743 \\
\hline
\end{tabular}

Notes: Fraction Pending is computed as the fraction of Number of Cases Filed that are not resolved by September 30, 2000. Fraction Tried is computed as the fraction of cases resolved by September 30, 2000, that were tried to a verdict.

is minimal. ${ }^{24}$ However, the overall trial rate is less than $6 \%$ for personal injury cases and less than $8 \%$ for job discrimination cases (though this is a somewhat downward-biased estimate, given the censoring). Even a small amount of censoring is likely to seriously affect estimates of the trial rate. Thus, the fact that $2.3 \%$ of personal injury cases filed in 1996 are unresolved makes even this year unsuitable for the analysis of

24. In our earlier work we developed a number of parametric statistical models that accounted for the censoring (Eisenberg and Farber, 1997, pp. S103-S106). These models relied on strong parametric assumptions, but we were restricted to using data on cases filed from 1986-1994 and closed by September 30, 1994. Given the relatively smaller sample size, dropping cases filed in the latter part of the sample period was unfeasible. The longer time period used here makes it feasible to drop cases filed in the later years while preserving adequate sample sizes. 
trial rates. The fraction of personal injury cases that are unresolved (the censoring rate) falls to $0.15 \%$ for cases filed in 1994 . Thus, we limit our analysis of personal injury cases to cases filed 1979-1994 that were resolved by September 30, 2000, in order to be reasonably sure that censoring is not be a significant problem. ${ }^{25}$ The censoring rate falls off more gradually for job discrimination cases. The censoring rate is $1 \%$ for job discrimination cases filed in 1996, 0.5\% for cases filed in 1995, and $0.3 \%$ for cases filed in 1994. We also limit our analysis of job discrimination cases to those filed 1979-1994 that were resolved by September 30, $2000 .^{26}$

Although measuring the trial rate is straightforward, determining or even defining who wins at trial is not. The data are fairly limited on this question, and we define a party as winning if a judgment was entered for that party. The central problem with this measure is that just because a judgment was entered for a particular party does not mean that the party in fact "won." For example, a plaintiff who files suit expecting a substantial damage award may settle for or receive at trial a very small damage award. This case would be recorded as a judgment for the plaintiff, and we call this a plaintiff win. But the plaintiff might perceive this as a loss. It is also the case that information on the identity of the party for whom judgment was entered is missing in $10.4 \%$ of the cases with trial outcomes. ${ }^{27}$

The data record the broad legal category of each case. Table 4 lists these categories and shows (1) the number of cases in each category in our sample, (2) the rate at which cases in each category are resolved at trial, and (3) the rate at which cases ending in trial judgments are won by plaintiffs. The largest categories of personal injury (PI) cases are "motor vehicle," "other PI," "asbestos," and "PI product liability." There

25. Of the 324,581 personal injury cases filed between 1979 and 1994 , only 88 $(0.03 \%)$ were censored as of September 30, 2000. As discussed in note 22, we dropped all cases filed in two districts because of a large number of long-term pending cases. Of the 6,377 cases filed in these districts between 1979 and 1994, fully 1,690 (26.5\%) were pending as of September 30, 2000.

26. Of the 143,619 job discrimination cases filed between 1979 and 1994, only 95 $(0.07 \%)$ were censored as of September 30, 2000.

27. A portion (19.8\%) of the cases we code as missing had a judgment entered for both parties. The missing data problem is much more severe in cases resolved without a trial verdict, where $86.2 \%$ are missing information on the identity of the party for whom a judgment was entered. Presumably, these are largely cases that are dropped or settled without having a formal judgment entered in court. 
Table 4. Case Distribution and Outcomes by Case Category

\begin{tabular}{lrcccc}
\hline Case Category & $\begin{array}{c}\text { Cases } \\
\text { Count }\end{array}$ & $\begin{array}{c}\text { Gov Def } \\
\text { Fraction }\end{array}$ & $\begin{array}{c}\text { Gov Pltf } \\
\text { Fraction }\end{array}$ & $\begin{array}{c}\text { Trial } \\
\text { Rate }\end{array}$ & $\begin{array}{c}\text { Pltf Win } \\
\text { Rate }\end{array}$ \\
\hline Personal injury & & & & & \\
$\quad$ Airplane & 5,926 & 0.278 & - & 0.081 & 0.456 \\
$\quad$ Assault, libel, slander & 7,453 & 0.136 & - & 0.060 & 0.501 \\
$\quad$ Marine & 6,309 & 0.311 & - & 0.076 & 0.545 \\
Motor vehicle & 79,195 & 0.129 & - & 0.066 & 0.631 \\
Other PI & 81,503 & 0.198 & - & 0.079 & 0.449 \\
Medical PI & 18,904 & 0.403 & - & 0.112 & 0.367 \\
$\quad$ Asbestos & 52,375 & 0.003 & - & 0.010 & 0.683 \\
PI product liability & 72,916 & 0.045 & - & 0.049 & 0.286 \\
$\quad$ Total & 324,581 & 0.130 & - & 0.059 & 0.468 \\
Job discrimination & 143,619 & 0.085 & 0.044 & 0.101 & 0.267 \\
\hline
\end{tabular}

Notes: The number of cases consists of all lawsuits in the indicated categories filed in federal courts between July 1979 and December 1994 and resolved (dropped, settled, or tried to a verdict) by September 30,2000 . The trial rate is the fraction of cases that were tried to a verdict by September 30, 2000. The Plaintiff win rate is computed as the ratio of the number of cases in which a judgment was entered for the plaintiff after a trial verdict, divided by the number of cases in which a judgment was entered for one party or the other after a trial verdict.

is significant variation in the level of government involvement across legal categories, ranging from a low of $0.3 \%$ of asbestos cases having the federal government as defendant to a high of $40.3 \%$ of medical PI cases having the federal government as defendant. There is also a substantial difference in trial rates across categories, with the highest trial rates in "medical PI" and the lowest trial rates in "asbestos." Plaintiff win rates at trial vary substantially across personal injury case categories, from a low of $28.6 \%$ in "PI product liability" to a high of $68 \%$ in "asbestos" cases. Plaintiff win rates in job discrimination cases are quite low at $26.7 \%$.

\section{Empirical Results}

\subsection{Trial Rates-Government as Defendant}

Table 5 contains tabulations of trial rates by party identity and case category. As a benchmark, the first column of the table contains the trial rate for each case category for cases with private defendants. The second column contains the trial rates by case category for cases with the government as defendant. The prediction of the case selection model, summarized in Tables 1 and 2, for both personal injury and job discrimination cases is that trial rates will be higher in cases with the government as defendant, 
Table 5. Trial Rates by Party Identity and Case Category

\begin{tabular}{|c|c|c|c|c|c|}
\hline Case Category & Private & Gov Def & $\Delta$ Gov & Gov PItf & $\Delta$ Gov \\
\hline \multicolumn{6}{|l|}{ Personal Injury } \\
\hline Airplane & $\begin{array}{c}0.068 \\
(0.003)\end{array}$ & $\begin{array}{c}0.114 \\
(0.007)\end{array}$ & $\begin{array}{c}0.046 \\
(0.007)\end{array}$ & - & - \\
\hline Assault, libel, slander & $\begin{array}{c}0.062 \\
(0.003)\end{array}$ & $\begin{array}{c}0.046 \\
(0.009)\end{array}$ & $\begin{array}{c}-0.016 \\
(0.008)\end{array}$ & - & - \\
\hline Marine & $\begin{array}{c}0.065 \\
(0.003)\end{array}$ & $\begin{array}{c}0.101 \\
(0.007)\end{array}$ & $\begin{array}{c}0.036 \\
(0.006)\end{array}$ & - & - \\
\hline Motor vehicle & $\begin{array}{c}0.063 \\
(0.001)\end{array}$ & $\begin{array}{c}0.082 \\
(0.003)\end{array}$ & $\begin{array}{c}0.018 \\
(0.002)\end{array}$ & - & - \\
\hline Other PI & $\begin{array}{c}0.074 \\
(0.001)\end{array}$ & $\begin{array}{c}0.097 \\
(0.002)\end{array}$ & $\begin{array}{c}0.023 \\
(0.002)\end{array}$ & - & - \\
\hline Medical PI & $\begin{array}{c}0.110 \\
(0.002)\end{array}$ & $\begin{array}{c}0.116 \\
(0.003)\end{array}$ & $\begin{array}{c}0.005 \\
(0.003)\end{array}$ & - & - \\
\hline Asbestos & $\begin{array}{c}0.010 \\
(0.001)\end{array}$ & $\begin{array}{c}0.020 \\
(0.024)\end{array}$ & $\begin{array}{c}0.010 \\
(0.019)\end{array}$ & - & - \\
\hline PI product liability & $\begin{array}{c}0.047 \\
(0.001)\end{array}$ & $\begin{array}{c}0.075 \\
(0.005)\end{array}$ & $\begin{array}{c}0.027 \\
(0.004)\end{array}$ & - & - \\
\hline All PI & $\begin{array}{c}0.054 \\
(0.000)\end{array}$ & $\begin{array}{c}0.094 \\
(0.001)\end{array}$ & $\begin{array}{c}0.040 \\
(0.001)\end{array}$ & - & - \\
\hline Job discrimination & $\begin{array}{c}0.101 \\
(0.001)\end{array}$ & $\begin{array}{c}0.120 \\
(0.003)\end{array}$ & $\begin{array}{c}0.019 \\
(0.003)\end{array}$ & $\begin{array}{c}0.067 \\
(0.004)\end{array}$ & $\begin{array}{r}-0.034 \\
(0.004)\end{array}$ \\
\hline
\end{tabular}

Notes: The sample consists of all lawsuits in the indicated categories filed in federal courts between July 1979 and December 1994 and resolved (dropped, settled, or tried to a verdict) by September 30, 2000. The trial rate is the fraction of cases that were tried to a verdict by September 30, 2000. The $\Delta$ Gov column reports the differences in trial rates between cases with the indicated government parties and the trial rate in cases with private parties. There are no personal injury cases with government as plaintiff. Sample sizes are contained in Table 4 . The numbers in parentheses are standard errors.

and the tabulations are consistent with this prediction. The third column of the table contains the difference in trial rates between cases with the government as defendant and cases with private defendants. Overall, trial rates are 4.0 percentage points higher in personal injury cases with the government as defendant $(p<.0005)$. Substantively, the 4.0-point difference is substantial, implying that trial rates in personal injury cases with the government as defendant are fully $74 \%$ higher than trial rates in those with private defendants. The difference in trial rates is somewhat smaller, though still significant, at 1.9 percentage points in job discrimination cases $(p<.0005)$. This implies that trial rates are $19 \%$ higher in job discrimination cases with government defendants than in those with private defendants. Within the personal injury cases the trial rates are higher in cases with the government as defendant in all case categories save one 
("assault, libel, slander"), and the differences are statistically significant at conventional levels in all but "asbestos" and "medical PI" cases. ${ }^{28}$

It is possible that the mix of personal injury cases differs for private and government defendants. Trial rates are known to differ across categories of personal injury tort cases. For example, medical malpractice cases have high trial rates, compared to all other classes of personal injury tort cases (Eisenberg et al., 1996). This is true for both state and federal court cases. However, it is unlikely that the difference in trial rates for the aggregated personal injury category is the result of a different mix of personal injury cases' being filed against government and private defendants, because the trial rates in virtually every category are higher for cases with the government as defendant.

Potentially more important is the possibility that the mix of cases and outcomes has varied over time or varies systematically across district courts in ways that make it appear the trial rate is higher in cases with the government as defendant. In order to investigate these possibilities, we estimated probit models of the probability of a trial that include fixed effects for case category (eight categories for personal injury and one category for job discrimination), year of filing (16 years), and federal court district (89 districts). ${ }^{29}$ These results are contained in Tables 6 and 7.

Based on the estimates in Table 6, the probit estimate of the raw 3.4 percentage point difference in trial rates in personal injury cases is reduced by over half (to 1.4 percentage points), controlling for case category. ${ }^{30}$ Controlling for year of filing alone reduces the difference from 3.4 points

28. The "assault, libel, slander" category is conceptually awkward because it lumps together quite different torts. Furthermore, assault cases may well be qualitatively different as between government and private defendants. Assaults involving government defendants have civil rights overtones that are lacking in assault cases involving private defendants. However, we expect that most assault cases involving government officials would appear in the Administrative Office Data's civil rights categories, not its tort categories.

29. The analysis of personal injury cases uses data from 89 of the 91 federal districts because of the large number of pending cases in two districts. See notes 22 and 25 and the related discussion.

30. The fact that the normalized probit estimate in column 1 of Table 6 shows a 3.4 percentage point raw difference while column 3 of Table 5 shows a 4.0 percentage point difference is due to the nonlinear nature of the probit model. We have reestimated all of the probit models presented in Tables $6-8$ and $10-12$, using linear probability models (guaranteed to go through the mean), and the results are substantively unchanged. 
Table 6. Effect of Defendant Identity on Trial Rates, Normalized Probit Estimates: Personal Injury Cases

\begin{tabular}{lccccc}
\hline & $(\mathbf{1})$ & $(\mathbf{2})$ & $\mathbf{( 3 )}$ & $\mathbf{( 4 )}$ & $\mathbf{( 5 )}$ \\
\hline$\Delta$ Gov & 0.034 & 0.014 & 0.026 & 0.035 & 0.016 \\
& $(0.001)$ & $(0.001)$ & $(0.001)$ & $(0.001)$ & $(0.001)$ \\
Case category & No & Yes & No & No & Yes \\
Year of filing & No & No & Yes & No & Yes \\
District court & No & No & No & Yes & Yes \\
\hline
\end{tabular}

Notes: $\Delta \mathrm{Gov}$ is the normalized coefficient on a dummy variable for government defendant in a probit model of the probability of a trial verdict on the indicated control variables. As such, it represents the adjusted difference in trial rates between cases with the government as defendant and the trial rate in cases with private defendants. The coefficient is normalized to represent the derivative of the probability of the outcome with respect to a change in the explanatory variable. This is computed as $\hat{\beta} \phi(\bar{X} \hat{\beta})$, where $\hat{\beta}$ is the vector of estimated parameters of the probit model, $\bar{X}$ is the vector of means of the explanatory variables, and $\phi$ is the standard normal probability density function. The sample consists of 300,124 personal injury lawsuits filed in federal courts between July 1979 and December 1994 and resolved (dropped, settled, or tried to a verdict) by September 30, 2000. The trial rate is the fraction of cases that were tried to a verdict by September 30, 2000. There are eight case categories, 16 filing years, and 89 district courts. The numbers in parentheses are standard errors.

to 2.6 points. Controlling for the district court does not affect the difference. Overall, controlling for case category, filing year, and district court reduces the raw difference from 3.4 points to 1.6 points. This difference remains strongly statistically significant and is consistent with the prediction of our model.

Table 7. Effect of Defendant Identity on Trial Rates, Normalized Probit Estimates: Job Discrimination Cases

\begin{tabular}{lcccc}
\hline & $\mathbf{( 1 )}$ & $(\mathbf{2})$ & $\mathbf{( 3 )}$ & $\mathbf{( 4 )}$ \\
\hline$\Delta$ Gov & 0.018 & 0.017 & 0.020 & 0.019 \\
& $(0.003)$ & $(0.003)$ & $(0.003)$ & $(0.003)$ \\
Year of filing & No & Yes & No & Yes \\
District court & No & No & Yes & Yes \\
\hline
\end{tabular}

Notes: $\Delta$ Gov is the normalized coefficient on a dummy variable for government defendant in a probit model of the probability of a trial verdict on the indicated control variables. As such, it represents the adjusted difference in trial rates between cases with the government as defendant and the trial rate in cases with private defendants. The coefficient is normalized to represent the derivative of the probability of the outcome with respect to a change in the explanatory variable. This is computed as $\hat{\beta} \phi(\bar{X} \hat{\beta})$, where $\hat{\beta}$ is the vector of estimated parameters of the probit model, $\bar{X}$ is the vector of means of the explanatory variables, and $\phi$ is the standard normal probability density function. The sample consists of 137,192 job discrimination lawsuits filed in federal courts by private plaintiffs between July 1979 and December 1994 and resolved (dropped, settled, or tried to a verdict) by September 30, 2000. The trial rate is the fraction of cases that were tried to a verdict by September 30, 2000. There are 16 filing years and 91 district courts. The numbers in parentheses are standard errors. 
Similar estimates for job discrimination cases are contained in Table 7. The raw difference of 1.8 percentage points is not affected significantly by the inclusion of the control variables. Controlling for filing year and district court leaves the point estimate of the raw difference unchanged. Once again, this difference remains strongly statistically significant and is consistent with the prediction of our model.

\subsection{Trial Rates-Government as Plaintiff}

Our analysis of the government as plaintiff focuses only on job discrimination cases. The entry in the fourth column of Table 5 contains the trial rate for job discrimination cases with the government as plaintiff. The prediction of the case selection model for job discrimination cases is that trial rates will be lower in cases with the government as plaintiff, and the tabulations are consistent with this prediction. The fifth column of the table contains the difference in trial rates between cases with the government as plaintiff and cases with private plaintiffs. Trial rates are 3.4 percentage points lower in job discrimination cases with the government as plaintiff $(p<.0005)$.

Once again, in order to consider the role of filing year and federal court district, we estimated probit models of the probability of a trial verdict that include fixed effects in these dimensions. These estimates are contained in Table 8 . The normalized probit estimate of the raw difference is

Table 8. Effect of Plaintiff Identity on Trial Rates, Normalized Probit Estimates: Job Discrimination Cases

\begin{tabular}{lcccc}
\hline & $(\mathbf{1})$ & $\mathbf{( 2 )}$ & $\mathbf{( 3 )}$ & $\mathbf{( 4 )}$ \\
\hline$\Delta$ Gov & -0.039 & -0.037 & -0.035 & -0.032 \\
& $(0.004)$ & $(0.004)$ & $(0.004)$ & $(0.004)$ \\
Year of filing & No & Yes & No & Yes \\
District court & No & No & Yes & Yes \\
\hline
\end{tabular}

Notes: $\Delta \mathrm{Gov}$ is the normalized coefficient on a dummy variable for government plaintiff in a probit model of the probability of a trial verdict on the indicated control variables. As such, it represents the adjusted difference in trial rates between cases with the government as plaintiff and the trial rate in cases with private plaintiffs. The coefficient is normalized to represent the derivative of the probability of the outcome with respect to a change in the explanatory variable. This is computed as $\hat{\beta} \phi(\bar{X} \hat{\beta})$, where $\hat{\beta}$ is the vector of estimated parameters of the probit model, $\bar{X}$ is the vector of means of the explanatory variables, and $\phi$ is the standard normal probability density function. The sample consists of 131,297 job discrimination lawsuits filed in federal courts against private defendants between July 1979 and December 1994 and resolved (dropped, settled, or tried to a verdict) by September 30, 2000. The trial rate is the fraction of cases that were tried to a verdict by September 30, 2000. There are 16 filing years and 91 district courts. The numbers in parentheses are standard errors. 
-3.9 points, and controlling for filing year alone and district court alone have only a very small effect on the estimated difference. The raw difference is reduced to -3.2 percentage points by the inclusion of both sets of control variables. This difference remains strongly statistically significant and is consistent with the prediction of our model.

\subsection{Plaintiff Win Rates-Government as Defendant}

Table 9 contains tabulations of plaintiff win rates at trial by party identity and case category. As a benchmark, the first column of the table contains the plaintiff win rate for each case category for cases with private defendants. The second column contains the win rate by case category for cases with the government as defendant. The prediction of the case

Table 9. Plaintiff Win Rates at Trial by Party Identity and Case Category

\begin{tabular}{|c|c|c|c|c|c|}
\hline Case Category & Private & Gov Def & $\Delta$ Gov & Gov PIntf & $\Delta$ Gov \\
\hline \multicolumn{6}{|l|}{ Personal Injury } \\
\hline Airplane & $\begin{array}{c}0.464 \\
(0.030)\end{array}$ & $\begin{array}{c}0.442 \\
(0.038)\end{array}$ & $\begin{array}{r}-0.022 \\
(0.048)\end{array}$ & - & - \\
\hline Assault, libel, and slander & $\begin{array}{c}0.525 \\
(0.025)\end{array}$ & $\begin{array}{c}0.311 \\
(0.073)\end{array}$ & $\begin{array}{c}-0.214 \\
(0.076)\end{array}$ & - & - \\
\hline Marine & $\begin{array}{c}0.528 \\
(0.031)\end{array}$ & $\begin{array}{c}0.568 \\
(0.037)\end{array}$ & $\begin{array}{c}0.041 \\
(0.048)\end{array}$ & - & - \\
\hline Motor vehicle & $\begin{array}{c}0.624 \\
(0.008)\end{array}$ & $\begin{array}{c}0.666 \\
(0.018)\end{array}$ & $\begin{array}{c}0.042 \\
(0.019)\end{array}$ & - & - \\
\hline Other PI & $\begin{array}{c}0.460 \\
(0.007)\end{array}$ & $\begin{array}{c}0.418 \\
(0.013)\end{array}$ & $\begin{array}{c}-0.042 \\
(0.015)\end{array}$ & - & - \\
\hline Medical PI & $\begin{array}{c}0.279 \\
(0.014)\end{array}$ & $\begin{array}{c}0.490 \\
(0.017)\end{array}$ & $\begin{array}{c}0.211 \\
(0.022)\end{array}$ & - & - \\
\hline Asbestos & $\begin{array}{c}0.684 \\
(0.025)\end{array}$ & $\begin{array}{c}0.000 \\
(0.490)\end{array}$ & $\begin{array}{r}-0.684 \\
(0.482)\end{array}$ & - & - \\
\hline PI product liability & $\begin{array}{c}0.282 \\
(0.009)\end{array}$ & $\begin{array}{c}0.346 \\
(0.032)\end{array}$ & $\begin{array}{c}0.065 \\
(0.033)\end{array}$ & - & - \\
\hline All PI & $\begin{array}{c}0.462 \\
(0.004)\end{array}$ & $\begin{array}{c}0.489 \\
(0.008)\end{array}$ & $\begin{array}{c}0.027 \\
(0.009)\end{array}$ & - & - \\
\hline Job discrimination & $\begin{array}{c}0.273 \\
(0.004)\end{array}$ & $\begin{array}{c}0.163 \\
(0.012)\end{array}$ & $\begin{array}{c}-0.110 \\
(0.013)\end{array}$ & $\begin{array}{c}0.447 \\
(0.023)\end{array}$ & $\begin{array}{l}0.174 \\
(0.023)\end{array}$ \\
\hline
\end{tabular}

Notes: The sample consists of all lawsuits in the indicated categories filed in federal courts between July 1979 and December 1994 and resolved by a trial verdict by September 30, 2000. The Plaintiff win rate is computed as the ratio of the number of cases in which a judgment was entered for the plaintiff after a trial verdict, divided by the number of cases in which a judgment was entered for one party or the other after a trial verdict. The $\Delta$ Gov column reports the differences in plaintiff win rates between cases with the indicated government parties and the plaintiff win rate in cases with private parties. There are no personal injury cases with government as plaintiff. Summary statistics are contained in Table 4. The numbers in parentheses are standard errors. 
Table 10. Effect of Defendant Identity on Plaintiff Win Rates, Normalized Probit Estimates: Personal Injury Cases

\begin{tabular}{lccccc}
\hline & $(\mathbf{1})$ & $\mathbf{( 2 )}$ & $\mathbf{( 3 )}$ & $\mathbf{( 4 )}$ & $\mathbf{( 5 )}$ \\
\hline$\Delta$ Gov & 0.027 & 0.035 & 0.027 & 0.014 & 0.020 \\
& $(0.009)$ & $(0.010)$ & $(0.009)$ & $(0.010)$ & $(0.011)$ \\
Case category & No & Yes & No & No & Yes \\
Year of filing & No & No & Yes & No & Yes \\
District court & No & No & No & Yes & Yes \\
\hline
\end{tabular}

Notes: $\Delta \mathrm{Gov}$ is the normalized coefficient on a dummy variable for government defendant in a probit model of the probability of a plaintiff win at trial on the indicated control variables. As such, it represents the adjusted difference in plaintiff win rates between cases with the government as defendant and the trial rate in cases with private defendants. The coefficient is normalized to represent the derivative of the probability of the outcome with respect to a change in the explanatory variable. This is computed as $\hat{\beta} \phi(\bar{X} \hat{\beta})$, where $\hat{\beta}$ is the vector of estimated parameters of the probit model, $\bar{X}$ is the vector of means of the explanatory variables, and $\phi$ is the standard normal probability density function. The sample consists of 19,216 personal injury lawsuits filed in federal courts between July 1979 and December 1994 and tried to a verdict by September 30, 2000. There are eight case categories, 16 filing years, and 89 district courts. The numbers in parentheses are standard errors.

selection model, summarized in Tables 1 and 2, for both personal injury and job discrimination cases is that plaintiff win rates will be higher in cases with the government as defendant. The third column of the table contains the difference in plaintiff win rates between cases with the government as defendant and cases with private defendants. The tabulations provide mixed evidence on this prediction. Overall, plaintiff win rates are 2.7 percentage points higher in personal injury cases with the government as defendant $(p<.0005)$ but 11.0 percentage points lower in job discrimination cases with the government as defendant $(p<.0005)$. Within the personal injury cases, the evidence is also mixed. Of the eight case categories, the point estimate of the difference is positive, as expected, in four and negative in four. Three of the four positive estimates are significantly positive at conventional levels and two of the four negative estimates are significantly different from zero at conventional levels. ${ }^{31}$

Estimates of probit models of plaintiff win rates at trial that control for case category, filing year, and federal court district are contained in Tables 10 and 11 for personal injury and job discrimination cases, respectively. Based on the estimates in Table 10, the raw 2.7 percentage point

31. One of the three contrary results is "assault, libel, slander," which, as we noted earlier, is a conceptually awkward category. See note 28 . 
Table 11. Effect of Defendant Identity on Plaintiff Win Rates, Normalized Probit Estimates: Job Discrimination Cases

\begin{tabular}{lcccc}
\hline & (1) & (2) & (3) & (4) \\
\hline$\Delta$ Gov & -0.123 & -0.124 & -0.129 & -0.131 \\
& $(0.014)$ & $(0.014)$ & $(0.015)$ & $(0.015)$ \\
Year of filing & No & Yes & No & Yes \\
District court & No & No & Yes & Yes \\
\hline
\end{tabular}

Notes: $\Delta \mathrm{Gov}$ is the normalized coefficient on a dummy variable for government defendant in a probit model of the probability of a plaintiff win at trial on the indicated control variables. As such, it represents the adjusted difference in the plaintiff win rate between cases with the government as defendant and the plaintiff win rate in cases with private defendants. The coefficient is normalized to represent the derivative of the probability of the outcome with respect to a change in the explanatory variable. This is computed as $\hat{\beta} \phi(\bar{X} \hat{\beta})$, where $\hat{\beta}$ is the vector of estimated parameters of the probit model, $\bar{X}$ is the vector of means of the explanatory variables, and $\phi$ is the standard normal probability density function. The sample consists of 14,129 job discrimination lawsuits filed in federal courts by private plaintiffs between July 1979 and December 1994 and tried to a verdict by September 30, 2000. There are 16 filing years and 91 district courts. The numbers in parentheses are standard errors.

difference in win rates in personal injury cases increases to 3.5 percentage points, controlling for case category. Controlling for year of filing alone does not change the raw difference substantially, but controlling for the district court moves the point estimate of the difference to near zero and insignificance. Overall, controlling for case category, filing year, and district court reduces the raw difference from 2.7 points to 2.0 points. This difference is marginally statistically significantly positive $(p=.056)$ and is consistent with the prediction of our model.

Similar estimates for job discrimination cases, where the probit estimate of the raw difference of -12.3 percentage points is not consistent with the predictions of the model, are contained in Table 11. The raw difference is not affected significantly by the inclusion of the control variables. Controlling for filing year and district court increases the point estimate of the raw difference from -12.3 points to -13.1 points, and the plaintiff win rate in job discrimination cases remains inconsistent with the selection model.

\subsection{Plaintiff Win Rates-Government as Plaintiff}

As before, our analysis of the government as plaintiff focuses only on job discrimination cases. The entry in the fourth column and last row of Table 9 contains the plaintiff win rate for job discrimination cases with 
Table 12. Effect of Plaintiff Identity on Plaintiff Win Rates, Normalized Probit Estimates: Job Discrimination Cases

\begin{tabular}{lcccc}
\hline & $(\mathbf{1})$ & $(\mathbf{2})$ & $\mathbf{( 3 )}$ & $\mathbf{( 4 )}$ \\
\hline$\Delta$ Gov & 0.158 & 0.156 & 0.156 & 0.154 \\
& $(0.022)$ & $(0.022)$ & $(0.022)$ & $(0.022)$ \\
Year of filing & No & Yes & No & Yes \\
District court & No & No & Yes & Yes \\
\hline
\end{tabular}

Notes: $\Delta \mathrm{Gov}$ is the normalized coefficient on a dummy variable for government plaintiff in a probit model of the probability of a plaintiff win at trial on the indicated control variables. As such, it represents the adjusted difference in the plaintiff win rate between cases with the government as plaintiff and the plaintiff win rate in cases with private plaintiffs. The coefficient is normalized to represent the derivative of the probability of the outcome with respect to a change in the explanatory variable. This is computed as $\hat{\beta} \phi(\bar{X} \hat{\beta})$, where $\hat{\beta}$ is the vector of estimated parameters of the probit model, $\bar{X}$ is the vector of means of the explanatory variables, and $\phi$ is the standard normal probability density function. The sample consists of 13,090 job discrimination lawsuits filed in federal courts by private plaintiffs between July 1979 and December 1994 and tried to a verdict by September 30, 2000. There are 16 filing years and 91 district courts. The numbers in parentheses are standard errors.

the government as plaintiff. The prediction of the case selection model for job discrimination cases is that plaintiff win rates will be higher in cases with the government as plaintiff, and the tabulations are consistent with this prediction. The fifth column of the table contains the difference in win rates between cases with the government as plaintiff and cases with private plaintiffs. Plaintiff win rates are 17.4 percentage points higher in job discrimination cases with the government as plaintiff $(p<.0005)$.

Once again, in order to consider the role of filing year and federal court district, we estimated probit models of the probability of a plaintiff win at trial. These estimates are contained in Table 12. The probit estimate of the raw difference in the plaintiff win rate of 17.4 percentage points is roughly unaffected by the inclusion of the control variables. Controlling for both filing year and court district reduces the point estimate of the difference in plaintiff win rates from 15.8 to 15.4 points. This difference remains strongly statistically significant and is consistent with the prediction of our model.

\subsection{Further Discussion of Results}

Our model's predictions about trial rates are strongly confirmed, but the model's ability to account for trial win rates is more limited. Why might this be? 
One potential answer is that there are omitted factors affecting the decision to file claims against the government. Specifically, plaintiffs may overestimate their chances of success against the government as compared to their estimates of the chances of success against private parties. Judges and juries may be more protective of the government than plaintiffs believe they will be (Eisenberg, 1989, pp. 1599-1600).

The model is especially vulnerable in its prediction that government defendants are more likely to lose job discrimination trials than are private defendants. In this area, it may be that plaintiffs' perceptions about levels of government discrimination are out of line with reality. If plaintiffs' perceptions about government discriminatory behavior are skewed, we should observe higher rates of job discrimination lawsuits against the United States per worker than we observe against private employers. This is in fact the case.

For example, in 1990 the federal government employed 3.26 million non-farm workers (U.S. Bureau of the Census 1998, Table A-51). The civilian labor force in that year consisted of approximately 115.5 million non-U.S. government workers (U.S. Census Bureau, 1998, Table A19). About $15 \%$ of workers are not covered by Title VII because of its limitation to large employers (Eisenberg and Schwab, 1988b, p. 602). ${ }^{32}$ This leaves about 98 million non-U.S. government workers covered by Title VII, roughly 30 times the number of U.S. government workers. Yet federal job discrimination lawsuits against non-U.S. government defendants run only roughly eight to nine times the number of job discrimination lawsuits against the United States. Job discrimination lawsuits are thus filed at a much higher rate against the United States than against private parties, as Donohue and Siegelman found (1993, p. 731). ${ }^{33}$ Unless the United States is massively more discriminatory than private parties,

32. Some of these workers could bring an action under $\S 1981$.

33. Sources of increased filings against the government include the existence of Civil Service protections and the fact that adverse employment decisions by the government can lead to due process complaints (Donohue and Siegelman, 1993, p. 731). Donohue and Siegelman identify other differences between government employees and private employees. These include a higher percentage of suits against the government involving workers who are working for their employer at the time of the suit, the absence of back-pay awards in such actions, the likely higher damages awards available because of relatively high wages in the federal sector, and the federal government's relatively high proportion of minority and female workers. 
this high claiming rate could be the source of the unexpectedly low trial win rate against the United States. ${ }^{34}$ A relatively weak class of cases may be being filed against the United States.

In comparison, the rate of personal injury tort claiming against the United States is much lower. In federal court alone, diversity actions filed against private parties are about nine to ten times the number of FTCA actions against the United States. And the diversity actions comprise a relatively small fraction of personal injury tort action. Most of it occurs in state court (Eisenberg et al., 1996). Thus, claiming rates against the United States in the personal injury tort area probably more accurately reflect the level of U.S. government misbehavior than do claiming rates against the United States in the job discrimination area. The United States appears to act as a magnet for job discrimination plaintiffs in a way that it does not for tort victims, and this may account for the difference in our findings regarding plaintiff win rates between the two areas. ${ }^{35}$

\section{Summary and Conclusion}

Overall, we found substantial support for the predictions of the case selection model, summarized in Table 2, for differences in case outcomes between the government and private litigants. The model generates six predictions for trial rates and plaintiff win rates for the categories of cases and roles for the government we study. Five of the six predictions are

34. In fact, the federal government appears to be less discriminatory in employment on the basis of race and sex. For example, we find, using the February 1995 and February 1997 Current Population Surveys (CPSs), that, after controlling for education and age, the gap in wages between men and women and between whites and nonwhites is significantly smaller in the federal government than in the private sector. We find additionally that the fraction of nonwhites employed by the federal government is twice as high as the fraction of whites employed by the federal government, while there is no difference for females. These differences are probably due, at least in part, to the existence of the Civil Service System, which attempts to administer employment decisions in the federal government on race-neutral and sex-neutral grounds. For an early analysis with similar findings, see Smith (1977).

35. In the context of our model, the higher claiming rate against the government in job discrimination cases could be due either to lower plaintiff costs (pecuniary or nonpecuniary) or to relative optimism on the part of plaintiffs against the government regarding the likelihood of a trial victory (high $\theta_{p}$ ). In either case, our selection model predicts not only lower plaintiff win rates against the government but also the higher trial rates we predict and find for job discrimination cases with government defendants. 
supported by the data. The only deviation is that the plaintiff win rate in job discrimination cases with the government as defendant is lower than the plaintiff win rate in job discrimination cases with private defendants, whereas the model predicts the opposite relationship. This anomaly may be attributable to extraordinarily high job discrimination claiming rates against the United States.

This study's results are important in showing the power of modeling the case selection process carefully when evaluating case outcomes. The government goes to trial at a higher rate than private parties when it is defendant and at a lower rate than private parties when it is plaintiff. The government as defendant appears to lose more often than private defendants and the government as plaintiff appears to win more often than private plaintiffs. These findings are easily understood in the context of the case selection model, and they cannot be easily explained by theories that rely on such factors as differential quality of counsel. ${ }^{36}$

Other factors we do not consider here undoubtedly also influence trial rates and trial win rates. ${ }^{37}$ We do not deny that alternative explanations may exist for the patterns we predict and observe. However, our model's predictions about both trial rates and success rates in litigation as they relate to the identity of both plaintiffs and defendants helps to separate its implications from factors emphasized in other models, which often have implications for only a single outcome. ${ }^{38}$

A final point is that testing the case selection model is hampered by the likelihood that only a tiny fraction of potential claims are filed as lawsuits. Essentially, we are looking for the effects of the case selection model when only the "successes" are observed. That the model does as well as it does with such "partial observability" is encouraging in our view, but more direct evidence could come from settings where both cases selected and those not selected can be observed.

36. The results are also consistent in their support for the case selection model with the results of our earlier work, where we used the distinction between corporations and individuals as parties in diversity cases (Eisenberg and Farber, 1997).

37. For a survey and synthesis, see Kessler et al. (1996).

38. See Eisenberg and Farber (1997) for mention of alternative explanations. 


\section{References}

Americans with Disabilities Act, 42 U.S.C. §§ 12101-12117 (1994).

Bebchuk, Lucian A. 1984. "Litigation and Settlement under Imperfect Information," 15 RAND Journal of Economics 404-15.

Civil Rights Act of 1964, 42 U.S.C. § 2000e (1994).

Civil Rights Act of 1991, 42 U.S.C. $\S \S 1981$, 1981a (1994).

Clermont, Kevin M., and Theodore Eisenberg. 1992. "Trial by Jury or Judge: Transcending Empiricism," 77 Cornell Law Review 1124-77.

1995. "Exorcizing the Evil of Forum Shopping," 80 Cornell Law Review 1507-30.

Daniels, Stephen, and Joanne Martin. 1995. Civil Juries and the Politics of Reform. Chicago: Northwestern University Press.

Danzon, Patricia M. 1985. Medical Malpractice: Theory, Evidence and Public Policy. Cambridge, MA: Harvard University Press.

Daughety, Andrew F., and Jennifer F. Reinganum. 1994. "Settlement Negotiations with Two-Sided Asymmetric Information: Model Duality, Information Distribution, and Efficiency," 14 International Review of Law \& Economics 283-96.

Donohue, John J., III, and Peter Siegelman. 1991. "The Changing Nature of Employment Discrimination," 43 Stanford Law Review 983-1033.

1993. "Law and Macroeconomics: Employment Discrimination Litigation over the Business Cycle," 66 Southern California Law Review 709-65.

Eisenberg, Theodore. 1989. "Litigation Models and Trial Outcomes in Civil Rights and Prisoner Cases," 77 Georgetown Law Journal 1567-1602.

1991. "The Relationship between Plaintiff Success Rates before Trial and at Trial," 154 Journal of the Royal Statistical Society, Series A, Part 1, 111-16.

Eisenberg, Theodore, and Henry S. Farber. 1997. "The Litigious Plaintiff Hypothesis: Case Selection and Resolution," 28 RAND Journal of Economics S92S112.

Eisenberg, Theodore, John Goerdt, Brian Ostrom, and David Rottman. 1996. "Trial Outcomes in State and Federal Courts: A Statistical Portrait," 19 Seattle Law Review 433-53.

Eisenberg, Theodore, John Goerdt, Brian Ostrom, David Rottman, and Martin T. Wells. 1997. "The Predictability of Punitive Damages," 26 Journal of Legal Studies 623-61.

Eisenberg, Theodore, and Stewart Schwab. 1988a. "Explaining Constitutional Tort Litigation: The Influence of the Attorney Fees Statute and the Government As Defendant," 73 Cornell Law Review 719-84. 1988b. "The Importance of Section 1981," 73 Cornell Law Review 596604.

Farber, Henry S., and Max H. Bazerman. 1987. "Why Is There Disagreement in Bargaining?" 77 American Economic Review 347-52. 
1989. "Divergent Expectations As a Cause of Disagreement in Bargaining: Evidence from a Comparison of Arbitration Schemes," 104 Quarterly Journal of Economics 99-120.

Farber, Henry S., and Harry C. Katz. 1979. "Interest Arbitration, Outcomes, and the Incentive to Bargain," 33 Industrial and Labor Relations Review 55-63.

Federal Tort Claims Act, 28 U.S.C. §§ 1332(a), 1346(b), 2674-2675(a), 2680 (1994 \& Supp. V 1999).

Gould, John P. 1973. "The Economics of Legal Conflicts," 2 Journal of Legal Studies 279-300.

Hensler, Deborah R., M. Susan Marquis, Allan F. Abraham, Sandra H. Berry, Patricia A. Ebener, Elizabeth G. Lewis, E. Allan Lind, Robert J. MacCoun, Willard G. Manning, Jeanette A. Rogowski, and Mary E. Vaiana. 1991. Compensation for Accidental Injuries in the United States. Santa Monica, CA: RAND Institute for Civil Justice.

Hillman, Robert A. 1998. "Questioning the 'New Consensus' on Promissory Estoppal: An Empirical and Theoretical Study," 98 Columbia Law Review 580619.

Inter-University Consortium for Political and Social Research. Last updated April 25, 2002. Federal Court Cases: Integrated Data Base, 1970-2000. ICPSR Study No. 8429.

Jones Act, 46 U.S.C. § 688 (1994).

Kessler, Daniel, Thomas Meites, and Geoffrey Miller. 1996. "Explaining Deviations from the Fifty-Percent Rule: a Multimodal Approach to the Selection of Cases for Litigation," 25 Journal of Legal Studies 233-57.

Landes, William M. 1971. "An Economic Analysis of the Courts," 14 Journal of Law \& Economics 61-107.

Landes, William M., and Richard A. Posner. 1979. "Adjudication as a Private Good," 8 Journal of Legal Studies 235-84.

Moller, Erik. 1996. Trends in Civil Jury Verdicts Since 1985. Santa Monica, CA: RAND Institute.

Nash, John F., Jr. 1950. “The Bargaining Problem,” 18 Econometrica 155-62.

Posner, Richard A. 1973. "An Economic Approach to Legal Procedure and Administration," 2 Journal of Legal Studies 399-458.

Pub. L. No. 100-702, 102 Stat. 4642 (1988).

Pub. L. No. 101-336, 104 Stat. 228 (1990).

Pub. L. No. 102-166, 105 Stat. 1071 (1991).

Pub. L. No. 104-317, 110 Stat. 3847 (1996).

Reinganum, Jennifer F. 1982. "Strategic Search Theory," 23 International Economics Review 1-17.

Reinganum, Jennifer F., and Louis L. Wilde. 1986. "Settlement, Litigation, and the Allocation of Litigation Costs," 17 RAND Journal of Economics 557-66. 
The Report of the Harvard Medical Practice Study. 1990. Patients, Doctors, and Lawyers: Medical Injury, Malpractice Litigation, and Patient Compensation in New York. President and Fellows of Harvard College.

Salop, Steven C., and Lawrence J. White. 1986. "Economic Analysis of Private Antitrust Litigation," 74 Georgetown Law Journal 1001-64.

Shavell, Steven. 1996. "Any Frequency of Plaintiff Victory at Trial is Possible," 25 Journal of Legal Studies 493-501.

Smith, Sharon P. 1977. Equal Pay in the Public Sector. Princeton, NJ: Industrial Relations Section, Princeton University.

Spier, Kathryn. 1994. "Pretrial Bargaining and the Design of Fee-Shifting Rules," 25 RAND Journal of Economics 197-214.

U.S. Bureau of Justice Statistics. 1995. Special Report: Civil Justice Survey of State Courts, 1992: Tort Cases in Large Counties. Washington, DC: Bureau of Justice Statistics.

U.S. Bureau of the Census. 1998. State and Metropolitan Area Data Book. Washington, DC: U.S. Bureau of the Census 〈http://www.census.gov:80/statab/ www/smadb.html $>$.

\section{Case References}

Bergh v. Washington, 585 p. 2d 805 (Wash. App. 1978).

Berkovitz̈ v. United States, 486 U.S. 531 (1988).

Erie Railroad Co. v. Tompkins, 304 U.S. 64 (1938).

Florida Department of State v. Treasure Salvors, Inc., 458 U.S. 670 (1982).

Landgraf v. USI Film Prods., 511 U.S. 244 (1994).

United States v. Gaubert, 499 U.S. 315 (1991).

Welch v. State Department of Highways and Public Transportation, 483 U.S. 474 (1987). 